\title{
Research on the Impact of Corporate Social Responsibility on Consumers' Purchase Intention
}

\author{
Mengjun Yu, Jikai Wang, Jiao Xin \\ School of Business, Shandong University of Technology, Zibo, China \\ Email: 740210582@qq.com
}

How to cite this paper: $\mathrm{Yu}, \mathrm{M} . J$. , Wang, J.K. and Xin, J. (2021) Research on the Impact of Corporate Social Responsibility on Consumers' Purchase Intention. Open Access Library Journal, 8: e7672.

https://doi.org/10.4236/oalib.1107672

Received: June 21, 2021

Accepted: July 18, 2021

Published: July 21, 2021

Copyright $\odot 2021$ by author(s) and Open Access Library Inc.

This work is licensed under the Creative Commons Attribution International License (CC BY 4.0).

http://creativecommons.org/licenses/by/4.0/

\section{(c) (i) Open Access}

\begin{abstract}
This study built a model including corporate social responsibility (CSR), perception of product quality, consumers' purchase intention, and tested the influence of the CSR on consumers' purchase Intention and the moderating effect of perception of product quality through questionnaire method. The results show that CSR has direct positive influence on consumers' purchase intention, and there are differences in the positive impact on each dimension. The influence of charity, legal and environmental responsibility on consumers' purchase intention is positively moderated by the perception of product quality, and the influence of economic and consumer responsibility on consumers' purchase intention is negatively moderated by it.
\end{abstract}

\section{Subject Areas \\ Consumer Behavior}

\section{Keywords}

CSR, Perception of Product Quality, Consumers' Purchase Intention

\section{Introduction}

At the beginning of 2020, Wuhan, Hubei, the new crown virus is raging, and many companies rush to help Hubei. As of April 4th, nearly 4000 companies across the country have donated over 35.1 billion yuan to fight the epidemic, of which more than 50 companies have donated more than 100 million yuan [1]. These companies are involved in many industries such as medicine, real estate, education, and home furnishing. In addition to adopting the "one donation" approach, many companies have also expressed their concern for the public by 
assuming all aspects of social responsibilities, which have been well received by all sectors of society. However, in recent years, there have been many examples of neglecting social responsibilities in pursuit of profit maximization. There are still some companies that have not fulfilled their responsibilities to the society, ranging from the "contaminated milk powder" incident to the Foxconn employee jumping incident to the recent explosion. The "fake vaccine" incident of Changsheng Medicine, etc., has a serious lack of corporate social responsibility (CSR). Nowadays, the development of the times has put forward higher requirements for the performance of CSR in various industries, and how companies can better fulfill their social responsibilities in the development of the new era has become a hot topic today.

Related research shows that market consumers are concerned about the performance of corporate social responsibilities [2]. With the increasing awareness of environmental protection, safety, ethics, and the rule of law among market consumers, it is not feasible for companies to only pursue the maximization of economic profits while ignoring the fulfillment of social responsibilities. Related domestic and foreign studies have shown that the relatively high level of corporate social responsibility can have a positive impact on consumers' purchase intentions [3] [4]. In an environment where product quality and safety issues frequently occur, product quality will more sensitively affect consumers' final purchase intentions. The research on product quality perception and consumer purchase intention is relatively early, and the literature is quite abundant, but there are few literatures on the impact of product quality perception on consumer purchase intention in the context of CSR. In the research on the relationship between consumer purchase intention and CSR, there are relatively few literatures on choosing product quality perception as the moderating variable, so this article still has a certain degree of theoretical significance.

The two main issues that this study intends to solve are: 1) Does the social responsibility of different dimensions of the company affect and how does it affect consumers' purchase intentions? 2) How can product quality perception play a moderating role in the relationship between CSR and consumer purchase intentions? First, review the relevant literature and explain the relevant theoretical concepts; secondly, construct a conceptual model including five dimensions of corporate responsibility, consumer corporate social responsibility perception, product quality perception, and consumer purchase intentions. Product quality perception plays a positive regulatory role in the five groups of relationships; finally, collect samples of YL companies to conduct empirical research to explore the impact of CSR on consumers' purchase intentions, and discuss the regulatory role of product quality perception.

\section{Literature Review}

\subsection{Corporate Social Responsibility}

Bowen proposed the original definition of corporate social responsibility in 
1953: the obligation to formulate corporate policies or the actions taken to achieve the goals and values expected by society [5]. Frederick (1960) believes that the basic idea of corporate social responsibility is that enterprises have an obligation to improve society [6]. Ruben et al. (2017) believe that CSR is not only a company's fulfillment of legal and economic obligations to the society, but also other responsibilities that contribute to social development [7]. Carroll (1999) shows that CSR is an expectation, expecting that enterprises can satisfy consumers within a certain period of time [8]. Li Haiqin and Zhang Zigang (2010) divided CSR into six dimensions: economy, environment, employees, consumers, law, and charity [9]. Yang Haiting (2015) constructed the above six dimensions based on the consumer's perspective to establish the influence of the above six dimensions on consumers' purchase intentions. The model analyzes the mechanism of CSR performance on consumer purchase intention [10]. The definition and content of CSR have not been unified in the academic world. This study divides CSR into five dimensions of responsibility: economy, consumer, environment, law, and charity.

\subsection{Consumer Corporate Social Responsibility Perception}

Lichtenstein (2004) put forward the concept of "corporate social responsibility perception" [11]. Consumers' perception of corporate social responsibility is the consumer's association of CSR, and the consumer's evaluation and emotional response to corporate behavior. $\mathrm{Gu}$ (2005) found that customers will form a subjective sense of corporate social responsibility based on existing information, and will not show the same preference for all CSR activities. Even for the same kind of social responsibility behaviors implemented by enterprises [12], so consumers' perception of corporate social responsibility and CSR itself cannot be confused. Ramasamy (2009) believes that consumer perceptions of corporate social responsibility have the function of distinguishing the economic responsibility, moral responsibility, charity responsibility and legal responsibility of a company [13]. Berens (2005) found that consumers' association with CSR affects purchase behavior and willingness [14].

\subsection{Consumer Purchase Intention}

Feng Jianying (2006)'s point of view is: purchase intention is the probability of consumers buying a certain product [15]. Guo Ji (2013) defines consumer purchase intention as the degree of subjective intensity of consumers to the services and products of the enterprise, and this degree affects consumers' shopping behavior [16]. Zhang Jinxin (2016) believes that consumers' purchase intention is still in the stage of human subjective consciousness, not the stage of specific purchase behavior [17].

There are many factors that affect purchase intention. It is not only affected by individual characteristics and product characteristics, but also by CSR. Consumers first consider the price factor when choosing products, but today's market 
consumers also pay attention to the recognition and popularity of the product brand. The social responsibility performed by the company will affect consumers' perception of the company's services and products to a certain extent, thereby affecting the purchase intention.

\subsection{Product Quality Perception}

Product quality refers to the characteristics that a product has to adapt to the needs of social production and life consumption, and it is a concrete manifestation of the use value of a product. Lin Jianhuang (2004) found that product quality can directly affect customers' consumption decisions, but they cannot make an objective measure of product quality. What affects customers' consumption decisions is a subjective perception of product quality [18]. Maynes (1976) pointed out that there is no objective evaluation of product quality by customers in real life, but a highly subjective evaluation of product quality from the perspective of customers themselves [19]. It can be seen that the perception of product quality means consumers' perception of the quality of a certain product.

In summary, there are many studies on CSR and consumer purchase intentions, and many studies have confirmed that the two are positively correlated, but there are still relatively few studies that incorporate product quality perception into the relationship between the two.

\section{Models and Assumptions}

In view of the deficiencies of previous research, this article will establish a comprehensive research model on CSR, consumer perception of corporate social responsibility, product quality perception and consumer purchase intention, and empirically analyze the impact of corporate social responsibility on consumers' purchasing intention, so as to better practice for companies Provide theoretical support for social responsibility. The following will discuss the impact of CSR in five dimensions, including economic responsibility, environmental responsibility, consumer responsibility, legal responsibility, and charity responsibility, consumer perceptions of corporate social responsibility, and product quality perceptions on consumers' purchase intentions.

\subsection{The Impact of Corporate Social Responsibility on Consumers' Purchase Intention}

The stakeholder theory believes that, in addition to creating profits and being responsible to the company's shareholders, companies must also assume corresponding responsibilities to consumers, society, employees, and the environment. Consumers have the characteristics of "economic man" in the market, and the social responsibility behavior undertaken by enterprises can create tangible benefits for consumers or make consumers feel the transfer of benefits subjectively. Therefore, consumers have a positive response to CSR. 
The research of Sen and Bhattacharya (2001) proves that enterprises taking on social responsibilities such as employees and the environment can have a direct impact on consumers' purchasing behavior and increase consumers' willingness to purchase corporate goods and services [20]. Carrigan and Attalla (2001) found that consumers would refuse to buy products produced by animal cruelty companies, but they did not reject the products produced by companies that mistreated their employees [21]. Mohr and Webb (2001) studied consumer purchase intention from two aspects of public welfare and environmental protection [2]. Xiang Rong (2017) and others studied the six aspects of community responsibility, employee responsibility, consumer responsibility, integrity responsibility, environmental protection responsibility, and social welfare responsibility. The results show that there is a significant positive correlation between them and consumers' purchase intentions, and consumers give different responses to different dimensions of responsibility [22].

Studies have shown that consumers in the market tend to purchase products from companies that bear higher social responsibilities when there is little price difference between similar products [23]. The empirical research of Deng Xinming (2016) and Sun Xiaoli (2019) shows that CSR has a direct and positive impact on consumers' purchase intention [3] [4]. In summary, regarding the impact of CSR on consumers' purchase intentions, this article draws on previous research results and puts forward the following five hypotheses:

H1a: Economic responsibility has a positive impact on purchase intention;

H1b: Environmental responsibility has a positive impact on purchase intention; H1c: Consumer responsibility has a positive impact on purchase intention;

H1d: Legal liability has a positive impact on purchase intention;

H1e: Charity responsibility has a positive impact on purchase intention.

\subsection{The Impact of CSR on Consumers' Perception of Corporate Social Responsibility}

Consumers are the core stakeholders in business activities, so many companies are now willing to perform more social responsibilities in order to gain consumer recognition. Herpen (2003) believes that consumers in the market form an affirmation of the value of the enterprise itself through CSR perception [24]. In the research of Mohr and Webb (2001), it is found that consumers' perception of corporate image and purchase intention are different due to different levels of consumer support for CSR [2]. It can be inferred from this that CSR positively affects consumers' perception of corporate social responsibility, and the higher the perceived corporate social responsibility, the stronger the sense of identity.

In summary, this article proposes the following hypotheses:

H2a: Economic responsibility has a positive impact on consumers' perception of CSR;

H2b: Environmental responsibility has a positive impact on consumers' CSR perception; 
H2c: Consumer responsibility has a positive impact on consumer CSR perception;

H2d: Legal liability has a positive impact on consumers' perception of CSR; H2e: Charity responsibility has a positive impact on consumers' CSR perception.

\subsection{The Impact of Consumers' Perceptions of Corporate Social Responsibility on Purchase Intentions}

Most of the existing research on CSR is based on the full perception of consumers. However, in reality, people's perceptions are uneven, and most people usually don't know the level of CSR fulfillment. The research of Dong Yali and Li Xiaonan (2010) found that consumers' perceived ease of use affected by trust and perceived ease of use can increase consumers' purchasing intentions [25]. The research of Wang Xinyang et al. (2018) confirmed that consumers' perception of corporate social responsibility in the market positively affects their purchase intentions [26]. Companies actively undertaking CSR will make consumers perceive a higher sense of social responsibility, which will affect consumers' willingness to exercise the "economic ticket" in their hands.

In summary, this article proposes the following hypotheses:

H3: Consumers' perceptions of corporate social responsibility have a positive impact on purchase intentions.

\subsection{The Moderating Effect of Product Quality Perception}

In consumer purchasing behavior and decision-making, product quality perception is an important factor that affects consumers' purchasing intention. Lee et al. (2018) believe that when consumers perceive higher product quality, their willingness to buy will be stronger [27]. Ariffin et al. (2016) found that the higher the quality evaluation of the product, the stronger the willingness of consumers to buy again [28]. Ma Longlong (2011) believes that consumers who purchase relatively high-quality products are generally more demanding and critical than ordinary people, have relatively high requirements for corporate social responsibility, and have a higher degree of loyalty [29]. Gao Xiang (2019) observed the influence of consumers' perceived quality on purchase intention and studied its moderating effect [30].

Therefore, consumers who often buy high-quality products are more likely to be affected by CSR. On the contrary, consumers who often buy low-quality products are not easily affected by CSR in their consumer behavior. This article introduces product quality perception into the influence relationship between CSR and purchase intention to explore its regulatory role.

In summary, this article proposes the following hypotheses:

H4a Product quality perception has a positive moderating effect on the relationship between economic responsibility and purchase intention.

H4b Product quality perception has a positive moderating effect on the rela- 
tionship between environmental responsibility and purchase intention.

$\mathrm{H} 4 \mathrm{c}$ product quality perception has a positive moderating effect on the relationship between consumer responsibility and purchase intention.

$\mathrm{H} 4 \mathrm{~d}$ product quality perception has a positive moderating effect on the relationship between mercy responsibility and purchase intention.

H4e product quality perception has a positive moderating effect on the relationship between legal liability and purchase intention.

Based on the above assumptions, this paper constructs a conceptual model including five dimensions of CSR, consumer perception of corporate social responsibility, perception of product quality, and consumer purchase intention, as shown in Figure 1.

\section{Research Method}

\subsection{Samples and Data}

Considering that dairy products have a huge potential consumer market in China, consumers in the Chinese market are generally familiar with the YL brand. At the same time, the safety of dairy products is an important part of food safety, and the social responsibility thinking of dairy companies needs more attention. Therefore, this article uses YL company as the research background. It is generally believed that the ratio of the number of samples to the number of observation variables is at least 10:1. Since there are 12 observation variables involved in this article, the number of samples is referenced to the ratio of the observation variables, so the number of samples issued is at least Is 120 . The survey adopted the method of distributing questionnaires online. A total of 218 questionnaires were distributed, and a total of 200 questionnaires were returned. The effective recovery rate is about $91.74 \%$. The statistical description is shown in Table 1.

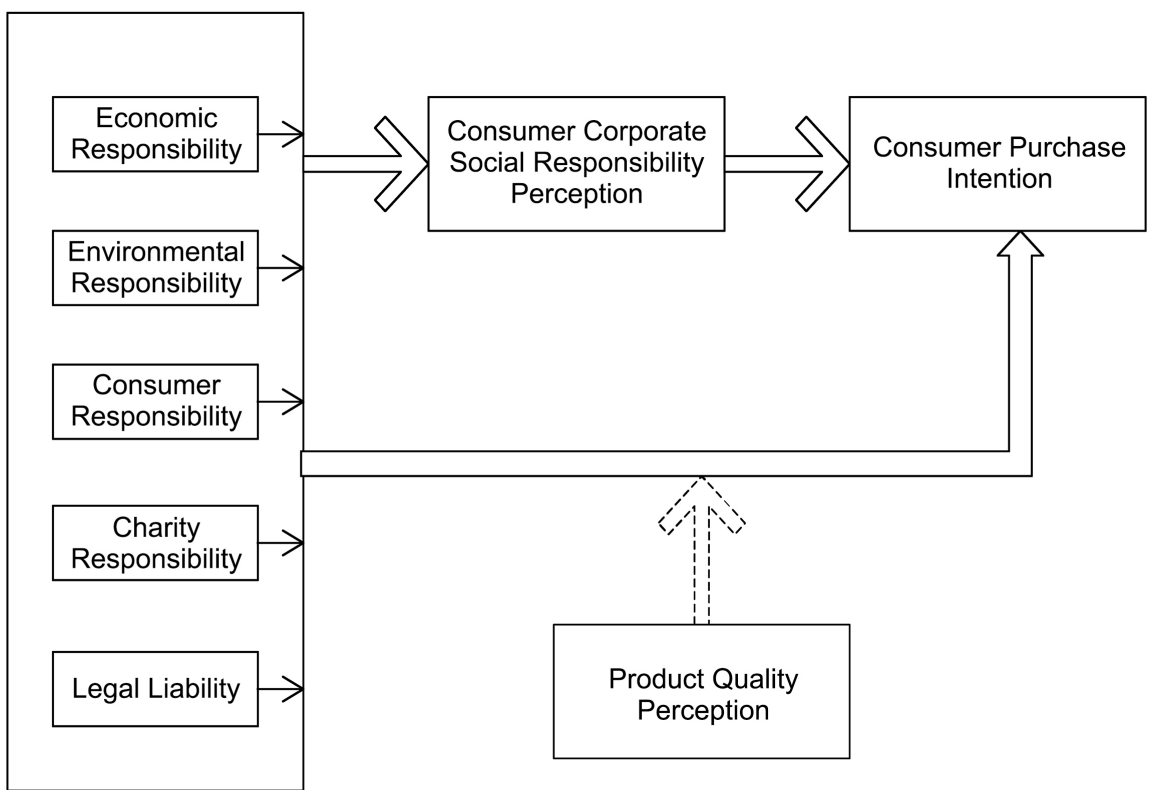

Figure 1. Research model. 
Table 1. Demographic characteristics of the sample $(n=200)$.

\begin{tabular}{|c|c|c|c|c|c|}
\hline Basic Information & Options & Proportion (\%) & Basic Information & Options & Proportion (\%) \\
\hline \multirow{2}{*}{ Gender } & Male & 44.0 & \multirow{6}{*}{ Age } & Under 19 years old & 25.0 \\
\hline & Female & 56.0 & & 20 - 30 years old & 51.0 \\
\hline \multirow{4}{*}{ Profession } & Corporate Practitioners & 33.5 & & 31 - 40 years old & 18.5 \\
\hline & Freelancer & 15.5 & & 41 - 50 years old & 22.0 \\
\hline & Student & 40.5 & & $51-60$ years old & 4.5 \\
\hline & Other & 10.5 & & Over 61 years old & 1.5 \\
\hline \multirow{5}{*}{$\begin{array}{l}\text { Ways to Buy Dairy } \\
\text { Products }\end{array}$} & Shopping Malls, Supermarkets & 83.5 & & Below 1500 yuan & 25.5 \\
\hline & Convenience Store & 52.0 & & $1501-2500$ yuan & 19.5 \\
\hline & Online Shopping & 54.5 & Monthly Income & $2501-3500$ yuan & 15.5 \\
\hline & Other & 8.5 & & $3501-4500$ yuan & 13.5 \\
\hline & & & & Above 4500 yuan & 26.0 \\
\hline
\end{tabular}

It can be seen from Table 1 that there are slightly more women than men in the sample group. This is because usually women are the purchasers of dairy products in the family; in terms of age, the age of the respondents is concentrated between 20 - 50 years old. -30-year-old young consumers account for more than half, and the elderly account for a small proportion. People under 19 years old are one of the main purchasers, accounting for $25 \%$ of the respondents, ranking second; in terms of income distribution, monthly The people with income below 4500 yuan accounted for the majority, and the ratio above $4500 \mathrm{yu}$ an was only $26.0 \%$.

\subsection{Questionnaires and Measurements}

The questionnaire consists of two parts. The first part is the main body of the questionnaire. The measurement items in this study are mainly derived from the relatively mature items in previous empirical studies by scholars. The CSR scale is mainly from Maignan (2001) [31], Lafferty (1999) [32] and Jin Liyin (2006) [33] developed the scale, consumer corporate social responsibility perception scale mainly refers to Berens (2007) [34], product quality perception scale refers to Yoo and Donthu (2001) [35], consumer purchase intention The scale comes from and Berens (2005) [14]. The above scale has been used in many domestic industries and has good measurement validity and reliability. [36] The second part is the information and characteristics of the survey object.

\subsection{Model Checking}

In order to verify the consistency of the scale measurement results, this paper conducted a reliability test on the collected data (Table 2). The Cronhach'a overall coefficient of the variable measurement scale is 0.970 , and the coefficients are all greater than $0.7(0.753-0.891)$, indicating that the measurement of each structural variable in this study has good validity. 
Factor analysis was used to test the structure validity. Before performing factor extraction, perform KMO and Bartlett sphere tests to determine whether factor analysis is feasible. It can be seen from Table 3 that the results show that the KMO values of each variable are $0.933,0.689,0.867,0.894$, which are all greater than 0.6 , and the concomitant probabilities sig. given by the Bartlett sphere test are all 0.000 , indicating that the item variables are suitable for factor analysis. Principal component analysis was used to test the validity of the four variables.

By performing factor analysis on the items of the CSR scale, and deleting items with small contributions one by one, the rotation component matrix of the table is obtained. As shown in Table 4, the results are shown as five factors, which are consistent with the previous division of CSR dimensions, which are charity, law, environment, consumers, and economic responsibility in order. The cumulative contribution rate of variance is $73.46 \%$, and the factor loading of each item is within the range of $0.512-0.787$, indicating that the validity of the CSR scale is acceptable.

Table 5 is the structural validity analysis of consumer corporate social responsibility perception, product quality perception and consumer purchase intention. Through the analysis, it can be concluded that each variable is a factor, and the factor loading of each item is greater than 0.8 , so it has Very good structure validity.

Table 2. Reliability analysis.

\begin{tabular}{|c|c|c|c|c|}
\hline \multicolumn{2}{|r|}{ Variable } & $\begin{array}{c}\text { Number of } \\
\text { items }\end{array}$ & Cronbach'a & $\begin{array}{c}\text { Overall } \\
\text { Cronbach'a }\end{array}$ \\
\hline \multirow{5}{*}{$\begin{array}{c}\text { Corporate Social } \\
\text { Responsibility }\end{array}$} & Economic Responsibility & 4 & 0.753 & \multirow{8}{*}{0.970} \\
\hline & Environmental Responsibility & 4 & 0.812 & \\
\hline & Consumer Responsibility & 5 & 0.866 & \\
\hline & Legal Liability & 4 & 0.853 & \\
\hline & Charity Responsibility & 5 & 0.859 & \\
\hline \multicolumn{2}{|c|}{ Consumer Corporate Social Responsibility Perception } & 3 & 0.760 & \\
\hline \multicolumn{2}{|c|}{ Product Quality Perception } & 5 & 0.881 & \\
\hline \multicolumn{2}{|c|}{ Consumer Purchase Intention } & 4 & 0.891 & \\
\hline
\end{tabular}

Table 3. KMO and Bartlett sphere inspection.

\begin{tabular}{ccccc}
\hline Variable & KMO & \multicolumn{3}{c}{ Bartlett Sphericity Test } \\
\cline { 3 - 5 } & & $\begin{array}{c}\text { Approximate } \\
\text { Chi-square }\end{array}$ & $\begin{array}{c}\text { Degree of } \\
\text { Freedom }\end{array}$ & Significance \\
\hline $\begin{array}{c}\text { Corporate Social Responsibility } \\
\text { Consumer Corporate Social } \\
\text { Responsibility Perception }\end{array}$ & 0.933 & 2807.620 & 231 & 0.000 \\
$\begin{array}{c}\text { Product Quality Perception } \\
\text { Consumer Purchase Intention }\end{array}$ & 0.689 & 146.861 & 3 & 0.000 \\
\hline
\end{tabular}


Table 4. CSR rotation component matrix.

\begin{tabular}{|c|c|c|c|c|c|}
\hline \multirow{2}{*}{ Item } & \multicolumn{5}{|c|}{ Ingredient } \\
\hline & 1 & 2 & 3 & 4 & 5 \\
\hline CSRe2 & 0.778 & & & & \\
\hline CSRe5 & 0.715 & & & & \\
\hline CSRe3 & 0.569 & & & & \\
\hline CSRe1 & 0.562 & & & & \\
\hline CSRe4 & 0.537 & & & & \\
\hline CSRd2 & & 0.746 & & & \\
\hline CSRd4 & & 0.715 & & & \\
\hline CSRb3 & & & 0.752 & & \\
\hline CSRb2 & & & 0.729 & & \\
\hline CSRb1 & & & 0.648 & & \\
\hline CSRb4 & & & 0.540 & & \\
\hline CSRc3 & & & & 0.774 & \\
\hline CSRc2 & & & & 0.543 & \\
\hline CSRc4 & & & & 0.530 & \\
\hline CSRc5 & & & & 0.512 & \\
\hline CSRa2 & & & & & 0.787 \\
\hline CSRa3 & & & & & 0.723 \\
\hline
\end{tabular}

Note: a1-e5 respectively represent the five variables of economy, environment, consumer, charity and legal responsibility.

Table 5. Component matrix of each variable.

\begin{tabular}{cccccc}
\hline Item & Ingredient & Item & Ingredient & Item & Ingredient \\
\hline $\begin{array}{c}\text { Consumers' Perception of } \\
\text { Corporate Social Responsibility }\end{array}$ & \multicolumn{2}{c}{$\begin{array}{c}\text { Consumer Purchase } \\
\text { Intention }\end{array}$} & \multicolumn{2}{c}{$\begin{array}{c}\text { Product Quality } \\
\text { Perception }\end{array}$} \\
\hline CP1 & 0.808 & CPI1 & 0.867 & PQ1 & 0.837 \\
CP2 & 0.81 & CPI2 & 0.872 & PQ2 & 0.804 \\
CP3 & 0.847 & CPI3 & 0.865 & PQ3 & 0.812 \\
& & CPI4 & 0.871 & PQ4 & 0.841 \\
& & & & PQ5 & 0.829 \\
\hline
\end{tabular}

Note: CP (1-3), CPI (1-4), PQ (1-5) respectively indicate Consumers' perceptions of corporate social responsibility, consumers' purchase intentions, and product quality perceptions.

\section{Outcome of Practice}

\subsection{Main Effect Analysis}

Linear regression method is used to test the hypothesis proposed in this paper, and the significance level and standardization coefficient between variables are measured. The results are shown in Table 6. 
Table 6. Regression analysis.

\begin{tabular}{ccccc}
\hline \multirow{2}{*}{ Dependent Variable } & Independent Variable & $\begin{array}{c}\text { Standardization } \\
\text { Factor }\end{array}$ & $\mathrm{t}$ & Significance \\
& Charity Responsibility & 0.404 & 9.575 & 0.000 \\
& Legal Liability & 0.331 & 7.847 & 0.000 \\
$\begin{array}{c}\text { Consumer Purchase } \\
\text { Intention }\end{array}$ & Environmental Responsibility & 0.360 & 8.534 & 0.000 \\
& Consumer Responsibility & 0.413 & 9.784 & 0.000 \\
& Economic Responsibility & 0.288 & 6.826 & 0.000 \\
\hline $\begin{array}{c}\text { Consumer Corporate } \\
\text { Social Responsibility } \\
\text { Perception }\end{array}$ & Chironmental Responsibility & 0.302 & 8.676 & 0.000 \\
& Consumer Responsibility & 0.399 & 11.439 & 0.000 \\
& Economic Responsibility & 0.189 & 5.412 & 0.000 \\
\hline $\begin{array}{c}\text { Consumer Purchase } \\
\text { Intention }\end{array}$ & $\begin{array}{c}\text { Consumer Corporate Social } \\
\text { Responsibility Perception }\end{array}$ & 0.747 & 15.824 & 0.000 \\
\hline
\end{tabular}

First of all, corporate charitable responsibility $(\beta=0.404, \mathrm{p}<0.001)$, legal responsibility $(\beta=0.331, \mathrm{p}<0.001)$, environmental responsibility $(\beta=0.360, \mathrm{p}<$ $0.001)$, consumer responsibility $(\beta=0.413, \mathrm{p}<0.001)$ and economic responsibility $(\beta=0.413, \mathrm{p}<0.001)$ are both positively and significantly related to consumers' purchase intentions. Therefore, it is assumed that H1a to H1e are valid.

Secondly, corporate charitable responsibility $(\beta=0.545, \mathrm{p}<0.001)$, legal responsibility $(\beta=0.426, \mathrm{p}<0.001)$, environmental responsibility $(\beta=0.302, \mathrm{p}<$ $0.001)$, Consumer responsibility $(\beta=0.399, \mathrm{p}<0.001)$ and economic responsibility $(\beta=0.189, \mathrm{p}<0.001)$ also have a positive and significant relationship with consumers' perceptions of corporate social responsibility, so suppose H2a to $\mathrm{H} 2 \mathrm{e}$ are established.

Finally, consumer perceptions of corporate social responsibility $(\beta=0.747, \mathrm{p}$ $<0.001$ ) have a positive and significant relationship with consumers' purchase intentions. Therefore, hypothesis $\mathrm{H} 3$ holds.

In summary, the basic hypothetical relationships H1a - H1e, H2a - H2e, and $\mathrm{H} 3$ in the model have all been verified.

\subsection{Moderating Effect}

Aiming at the moderating effect of product quality perception in this model, the total sample is divided into two sub-samples according to product quality perception, and regression analysis is performed. The results are shown in Table 7.

First of all, it can be seen that whether the product quality is at a high level or a low level, the five dimensions of CSR responsibility have a significant positive impact on consumers' purchase intentions. However, the degree of response of purchase intention to the five dimensions is different. When the product quality 
Table 7. Regression analysis of different product quality.

\begin{tabular}{|c|c|c|c|c|c|c|c|}
\hline \multirow{2}{*}{$\begin{array}{c}\text { Dependent } \\
\text { Variable }\end{array}$} & \multirow{2}{*}{ Independent Variable } & \multicolumn{3}{|c|}{ High level of product quality $(\mathrm{n} 1=160)$} & \multicolumn{3}{|c|}{ Low level of product quality $(\mathrm{n} 2=40)$} \\
\hline & & $\begin{array}{l}\text { Standardization } \\
\text { Factor }\end{array}$ & $\mathrm{t}$ & Significance & $\begin{array}{l}\text { Standardization } \\
\text { Factor }\end{array}$ & $\mathrm{t}$ & Significance \\
\hline \multirow{5}{*}{$\begin{array}{l}\text { Consumer } \\
\text { Purchase } \\
\text { Intention }\end{array}$} & Charity Responsibility & 0.434 & 8.250 & 0.000 & 0.304 & 1.932 & 0.062 \\
\hline & Legal Liability & 0.279 & 5.205 & 0.000 & 0.148 & 0.943 & 0.352 \\
\hline & Environmental Responsibility & 0.454 & 8.575 & 0.000 & 0.336 & 2.138 & 0.040 \\
\hline & Consumer Responsibility & 0.322 & 6.035 & 0.000 & 0.738 & 5.788 & 0.000 \\
\hline & Economic Responsibility & 0.300 & 5.646 & 0.000 & 0.348 & 2.737 & 0.010 \\
\hline
\end{tabular}

perception is high, the order of influence degree is: environmental responsibility $>$ charity responsibility $>$ consumer responsibility $>$ economic responsibility $>$ legal responsibility. When the product quality perception is low, the order of the degree of influence is: consumer responsibility $>$ economic responsibility $>$ environmental responsibility $>$ charity responsibility $>$ legal responsibility.

Secondly, it can be seen that when consumers perceive product quality at a high level, the two dimensions of the enterprise's economic and consumer responsibility have less influence on the purchase intention than when the product quality is low, which means that the increase in product quality perception weakens the purchase intention In response to the economic and consumer responsibilities of the enterprise, assume that $\mathrm{H} 4 \mathrm{a}$ and $\mathrm{H} 4 \mathrm{c}$ are not valid; it can also be seen that when consumers perceive product quality at a high level, the environmental, charity, and legal responsibilities of the enterprise have a greater impact on purchase intention than low-level products In terms of quality, that is to say, the improvement of product quality will increase the willingness to purchase to respond to corporate environment, charity and legal responsibilities. Suppose $\mathrm{H} 4 \mathrm{~b}, \mathrm{H} 4 \mathrm{~d}$, and H4e are established.

\section{Conclusions and Inspirations}

This article divides CSR into five dimensions, analyzes their influence on consumers' purchase intention, and further explores the moderating role of product quality perception in the five groups of relationships. The main research conclusions are as follows:

First, the five dimensions all have a direct and positive impact on consumers' purchase intentions, and indirectly affect purchase intentions through consumers' perceptions of corporate social responsibility.

According to Table 6, CSR in the five dimensions of charity, law, environment, consumers and economy can directly have a positive impact on consumers' purchasing intentions and has a significant relationship. Actively undertaking CSR will increase consumers' purchasing intentions. Companies should establish correct CSR awareness concept, and actively take social responsibility. Table 6 also shows that consumer perceptions of corporate social responsibility 
can have a positive impact on consumers' purchase intentions. The social responsibility activities implemented by companies will influence consumers' perceptions in the market to get rewards in terms of attracting new customers and maintaining old customers. People are more inclined to buy products from companies that actively undertake CSR.

In addition, the consumer responsibility dimension (0.413) has the greatest influence on purchase intention, while the influence of charity (0.404), environment (0.360), law (0.331) and economic (0.288) dimensions on purchase intention gradually decreases. Enterprises should make rational use of limited resources, guarantee product quality and consumer rights, first meet consumer needs, focus on consumer responsibilities, and then consider the performance of charity, environmental, legal, and economic responsibilities in turn.

Second, product quality perception has a positive moderating effect on the relationship between charity, legal and environmental responsibilities and consumers' purchase intentions, but it has a negative moderating effect on the relationship between economic and consumer responsibilities and consumers' purchase intentions.

For companies that produce low-end products, they must first actively assume their responsibilities to consumers, increase consumers' willingness to buy, and then pay attention to the performance of economic and environmental responsibilities in turn. For companies that produce higher-quality products, the marginal cost of improving quality will be greater than the marginal benefits. At this time, it should focus on fulfilling environmental and charitable responsibilities, improving the company's social image, and then taking into account consumer and economic responsibilities. Promote market recognition of corporate products and brands.

\section{Research Limitations and Prospects}

This article analyzes the impact of different dimensions of CSR on consumers' purchase intentions, and innovatively further explores the moderating effect of product quality perception on the above-mentioned relationship, providing a theoretical basis for enterprises to better practice social responsibility.

But there are still some limitations. First, the research object is a dairy company, which will affect the generality of the results to a certain extent. Secondly, in the process of consumers' purchasing intention being affected by CSR, the mediating and regulating effects of other factors need to be considered. In future research, different industries can be considered to comprehensively explore the impact of CSR and consumers' purchasing intentions, and provide more specific and feasible guidance and suggestions for Chinese companies to fulfill their social responsibilities.

\section{Conflicts of Interest}

The authors declare no conflicts of interest. 


\section{References}

[1] 《企业抗击疫情研究报告》在京发布 $[\mathrm{EB} / \mathrm{OL}]$. 人民政协网. http://www.rmzxb.com.cn/c/2020-04-15/2556054.shtml, 2020-04-15.

[2] Mohr, L.A., Webb, D.J. and Harris, K.E. (2001) Do Consumers Expect Companies to Be Socially Responsible? The Impact of Corporate Social Responsibility on Buying Behavior. Journal of Consumer Affairs, 35, 45-72. https://doi.org/10.1111/j.1745-6606.2001.tb00102.x

[3] 邓新明, 张婷, 许洋, 龙贤义. 企业社会责任对消费者购买意向的影响研究 [J]. 管理学报, 2016, 13(7): 1019-1027.

[4] 孙小丽. 企业社会责任与品牌价值的关系研究一一基于食品行业消费者购买意 愿的实证分析[J]. 价格理论与实践, 2019(7): 116-119.

[5] Bowen, H.R. and Johnson, F.E. (1953) Social Responsibility of the Businessman. Harper \& Brothers, New York.

[6] Frederick, W.C. (1960) The Growing Concern over Business Responsibility. California Management Review, 2, 54-61. https://doi.org/10.2307/41165405

[7] Ruben, B., Joshua, L. and Davar, R. (2017) Analysing the Effects of Teaching Approach on Engagement, Satisfaction and Future Time Perspective among Students in a Course on CSR. International Journal of Management Education, 15, 306-317. https://doi.org/10.1016/j.ijme.2017.02.003

[8] Carroll, A.B. (1999) Corporate Social Responsibility: Evolution of a Definitional Construct. Business \& Society, 38, 268-295. https://doi.org/10.1177/000765039903800303

[9] 李海芹, 张子刚. CSR 对企业声誉及顾客忠诚影响的实证研究[J]. 南开管理评论, 2010, 13(1): 90-98.

[10] 杨海婷. 企业社会责任绩效表现对消费者购买意愿的影响研究[D]: [硕士学位论 文]. 哈尔滨: 哈尔滨理工大学, 2015.

[11] Lichtenstein, D.R., Drumwright, M.E. and Braig, B.M. (2004) The Effect of Corporate Social Responsibility on Customer Donations to Corporate-Supported Nonprofits. Journal of Marketing, 68, 16-32. https://doi.org/10.1509/jmkg.68.4.16.42726

[12] Gu, H. and Morrison, P. (2009) An Examination of the Formation of Consumer CSR Association: When Corporate Social Responsible Initiatives Are Effective. $A C R$ Asia-Pacific Advances, 8, 68-75.

[13] Ramasamy, B. and Yeung, M. (2009) Chinese Consumers' Perception of Corporate Social Responsibility (CSR). Journal of Business Ethics, 88, 119-132. https://doi.org/10.1007/s10551-008-9825-x

[14] Berens, G., Van Riel, C.B.M. and Van Bruggen, G.H. (2005) Corporate Associations and Consumer Product Responses: The Moderating Role of Corporate Brand Dominance. Journal of Marketing, 69, 35-48. https://doi.org/10.1509/jmkg.69.3.35.66357

[15] 冯建英, 穆维松, 傅泽田. 消费者的购买意愿研究综述 [J]. 现代管理科学, 2006(11): 7-9.

[16] 郭际, 吴先华, 叶卫美. 转基因食品消费者购买意愿实证研究基于产品知识、感 知利得、感知风险和减少风险策略的视角 [J]. 技术经济与管理研究, 2013(9): 46.

[17] 张金金签海. 基于消费者品牌认知下的在线负面评论 [J]. 企业经济, 2016(7): 29-34.

[18] 林建煌. 消费者行为[M]. 北京: 北京大学出版社, 2004: 41-42.

[19] Maynes, E.S. (1976) The Concept and Measurement of Product Quality. In: House- 
hold Production and Consumption, NBER, Washington DC, 529-584.

[20] Sen, S. and Bhattacharya, C.B. (2001) Does Doing Good Always Lead to Doing Better? Consumer Reactions to Corporate Social Responsibility. Journal of Marketing Research, 38, 225-243. https://doi.org/10.1509/jmkr.38.2.225.18838

[21] Carrigan, M. and Attalla, A. (2001) The Myth of the Ethical Consumer-Do Ethics Matter in Purchase Behaviour? Journal of Consumer Marketing, 18, 560-578. https://doi.org/10.1108/07363760110410263

[22] 向荣. 企业社会责任行为与消费者响应研究: 基于消费者的视角 [C]//中国管理现 代化研究会, 复旦管理学奖励基金会. 第十二届(2017)中国管理学年会论文集, 2017: 756-766.

[23] Öberseder, M., Schlegelmilch, B.B. and Gruber, V. (2011) "Why Don’t Consumers Care about CSR?": A Qualitative Study Exploring the Role of CSR in Consumption Decisions. Journal of Business Ethics, 104, 449-460.

https://doi.org/10.1007/s10551-011-0925-7

[24] Van Herpen, E., Pennings, J.M.E. and Meulenberg, M.T.G. (2003) Consumers' Evaluations of Socially Responsible Activities in Retailing.

[25] 董雅丽, 李晓楠. 网络环境下感知风险、信任对消费者购物意愿的影响研究 [J]. 科技管理研究, 2010, 30(21): 134-137.

[26] 王欣洋. 消费者对企业社会责任的感知对其购买意愿的影响研究 [J]. 现代商业, 2018(3): 16-17.

[27] Lee, Y.G., Joo, H.C. and Lee, M.S. (2018) The Relationship among the Personal Service Quality, Customer Impression, Trust and Future Behavior Intention in Screen Golf Club. Korean Journal of Sports Science, 27, 515-531. https://doi.org/10.35159/kjss.2018.02.27.1.515

[28] Ariffin, S., Yusof, J.M., Putit, L., et al. (2016) Factors Influencing Perceived Quality and Repurchase Intention towards Green Products. Procedia Economics and Finance, 37, 391-396. https://doi.org/10.1016/S2212-5671(16)30142-3

[29] 马龙龙. 企业社会责任对消费者购买意愿的影响机制研究[J]. 管理世界, 2011(5): 120-126.

[30] 高翔. 消费者感知质量对线上购买意愿的影响机理研究 [J]. 商业经济研究, 2019(6): 73-76.

[31] Maignan, I. (2001) Consumers' Perceptions of Corporate Social Responsibilities: A Cross-Cultural Comparison. Journal of Business Ethics, 30, 57-72.

https://doi.org/10.1023/A:1006433928640

[32] Lafferty, B.A. and Goldsmith, R.E. (1999) Corporate Credibility's Role in Consumers' Attitudes and Purchase Intentions When a High versus a Low Credibility Endorser Is Used in the Ad. Journal of Business Research, 44, 109-116. https://doi.org/10.1016/S0148-2963(98)00002-2

[33] 金立印. 企业声誉、行业普及率与服务保证有效性一一消费者响应视角的实验研 究[J]. 管理世界 2009(7): 115-125.

[34] Berens, G., Van Riel, C.B.M. and Van Rekom, J. (2007) The CSR-Quality Trade-Off: When Can Corporate Social Responsibility and Corporate Ability Compensate Each Other? Journal of Business Ethics, 74, 233-252. https://doi.org/10.1007/s10551-006-9232-0

[35] Yoo, B. and Donthu, N. (2001) Developing and Validating a Multidimensional Consumer-Based Brand Equity Scale. Journal of Business Research, 52, 1-14. https://doi.org/10.1016/S0148-2963(99)00098-3

[36] 甘东玲. 消费者参与 CSR 的量表构建和研究 [J]. 经营与管理, 2019(4): 119-121. 